\title{
Grazing and growth of the heterotrophic flagellate Diphylleia rotans on the cyanobacterium Microcystis aeruginosa
}

\author{
Bo-Ra Kim ${ }^{1}$, Shin-ichi Nakano ${ }^{2}$, Baik-Ho Kim ${ }^{1}$, Myung-Soo Han ${ }^{1, *}$ \\ ${ }^{1}$ Department of Life Science, Hanyang University, Seoul 133-791, Korea \\ ${ }^{2}$ LAFWEDY, Faculty of Agriculture, Ehime University, Tarumi 3-5-7, Matsuyama, Ehime 790-8566, Japan
}

\begin{abstract}
The grazing and growth rates of the algivorous heterotrophic flagellate (HF) Diphylleia rotans were investigated on toxic (Microcystis aeruginosa NIER-10001, M. aeruginosa NIES-298, M. viridis NIES-102 and $M$. wesenbergii NIES-104) and non-toxic (M. aeruginosa NIES-101) Microcystis strains as well as other different algae such as the green alga Chlorella ${ }^{\mathrm{TM}}$ (Aquanet), and diatoms Cyclotella meneghiniana and Stephanodiscus hantzschii. The flagellate D. rotans showed active growth when fed $M$. aeruginosa and lower levels of growth when fed Chlorella ${ }^{\mathrm{TM}}$, but no growth when fed C. meneghiniana and S. hantzschii. The flagellate grew actively at $25^{\circ} \mathrm{C}$ and at a $\mathrm{pH}$ range between 6 and 9 . The highest maximum specific growth rate $\left(1.88 \mathrm{~d}^{-1}\right)$ and a high ingestion rate (27.0 prey $\mathrm{HF}^{-1} \mathrm{~d}^{-1}$ ) by D. rotans were observed when they were fed the most toxic of the 5 Microcystis strains, $M$. aeruginosa NIER-10001. These results suggest that $D$. rotans has a high tolerance to $M$. aeruginosa and may undergo microcystin-mediated growth.
\end{abstract}

KEY WORDS: Algivores - Heterotrophic flagellates · Diphylleia rotans · Microcystis spp. · Microcystin-mediated growth $\cdot$ Ingestion Resale or republication not permitted without written consent of the publisher

\section{INTRODUCTION}

Blooms of the cyanobacterium Microcystis aeruginosa are common in many eutrophic lakes and reservoirs where they may cause serious environmental problems such as a decreased recreational value, increased cost of water treatment and increased production of toxic and malodorous compounds. The physiology and ecology of $M$. aeruginosa have been extensively investigated, and many of the bloom-initiating mechanisms have been clarified (Nakano et al. 2001a). However, the factors acting against the proliferation of $M$. aeruginosa are less well understood.

In addition to environmental changes, such as decrease in water temperature and nutrient depletion (Paerl 1983), Microcystis populations may be subjected to 2 biological loss processes: grazing (Beveridge et al. 1993, Klaveness 1995, Zhang et al. 1996) and viral infection (Fuhrman \& Suttle 1993, Suttle 1994, Tucker \&
Pollard 2005). Grazing by higher trophic level organisms appears to be a major contributor to the loss of Microcystis blooms (Dryden \& Wright 1987). Many organisms graze on Microcystis spp., including fish (Miura 1990, Northcott et al. 1991), zooplankton (Hanazato \& Yasuno 1984) and protists (e.g. Dryden \& Wright 1987). Among these, the highly abundant protists may be the most important grazers of Microcystis spp. Previous laboratory studies have demonstrated that some species of flagellates, including the heterotrophic flagellate Collodictyon triciliatum and the mixotrophic flagellate Poterioochromonas sp. (Nishibe et al. 2002, Ou et al. 2005), and rhizopods (Nishibe et al. 2004) graze on Microcystis populations. While amoeboid grazing is relatively well understood there is less information regarding flagellate grazing on Microcystis populations.

We isolated a flagellate grazing on Microcystis aeruginosa from a hypereutrophic pond in Japan and 
examined the ecophysiology of this flagellate on its prey using comparisons of grazing behavior on toxic and non-toxic Microcystis strains, along with other algal strains, which represent different food types and qualities.

\section{MATERIALS AND METHODS}

Isolation and culture of the heterotrophic flagellate. Furuike Pond $\left(33^{\circ} 49^{\prime} 21^{\prime \prime} \mathrm{N}, 132^{\circ} 48^{\prime} 04^{\prime \prime} \mathrm{E}\right.$; altitude $40 \mathrm{~m}$ ) is an impoundment located in Sancho, Matsuyama City, Ehime Prefecture, Japan. It has a surface area of $7400 \mathrm{~m}^{2}$ and a maximum depth of $1.5 \mathrm{~m}$. The pond is hypereutrophic due to anthropogenic loading from the watershed (Nakano et al. 2001b) and is heavily populated by cyanobacteria, such as Microcystis aeruginosa and $M$. wesenbergii, from early summer to fall each year (Manage et al. 1999).

For isolation of a flagellate capable of grazing on $\mathrm{Mi}$ crocystis species, Microcystis aeruginosa NIES-298 was incubated in Cytophaga broth (CB) medium (MCC-NIES; www.nies.go.jp/biology/mcc/home_j.htm) and mixed with a pond water sample that had been filtered through a Nitex net (mesh size, $154 \mu \mathrm{m}$ ) for removal of larger zooplankton. This mixture was incubated at $25^{\circ} \mathrm{C}$ in the dark for 3 to $4 \mathrm{~d}$. Flagellates were isolated using a Pasteur micropipette under a light microscope. We established a monoclonal flagellate culture using a repetitive serial isolation process consisting of enrichment, dilution and single cell isolation steps. The isolated flagellate was maintained using a commercial strain of Chlorella ${ }^{\mathrm{TM}}$ (Aquanet) as prey. Water was collected from the Pal'tang Reservoir, Korea, filtered through a Whatman GF/F filter and sterilized in an autoclave to yield filtered sterilized water (FSW). A quantity of Chlorella ${ }^{\mathrm{TM}}$ was suspended in the FSW, and the flagellate was inoculated into the Chlorella ${ }^{\mathrm{TM}}$ suspension. We maintained the flagellate strain by inoculating it weekly into new Chlorella ${ }^{\mathrm{TM}}$ suspensions. Incubations were performed at $25^{\circ} \mathrm{C}$ under a light intensity of 40 to $45 \mu \mathrm{E} \mathrm{m}^{-2} \mathrm{~s}^{-1}$ of cool white fluorescent light, with a 12:12 h light:dark photoperiod.
To identify the flagellate, we used light and epifluorescence microscopy and $18 \mathrm{~S}$ rDNA sequencing. Morphological observations, including the presence of 2 long apical and equal flagella inserting near the anterior end at the top of the ventral groove formed by the curving lateral margins of the cell, a cell dimension of $15 \times 20 \mu \mathrm{m}$ (subject to change during feeding), and feeding observations such as free movement or rotation during feeding via the ventral groove, identified the flagellate as Diphylleia rotans (Massart 1920, Brugerolle \& Patterson 1990). This finding was confirmed by $18 \mathrm{~S}$ rDNA sequencing (authors' unpubl. data), which showed $99.8 \%$ homology with $D$. rotans Massart (Accession No. AF420478).

Cyanobacteria and diatom strains used as prey in this study. Five strains of Microcystis spp. were used, comprising 4 toxic strains (Microcystis aeruginosa NIER10001, M. aeruginosa NIES-298, M. viridis NIES-102, and $M$. wesenbergii NIES-104) and 1 non-toxic strain (M. aeruginosa NIES-101) (Table 1). M. aeruginosa NIER-10001 was obtained from the National Institute of Environmental Research (NIER), Korea, while the latter 4 cyanobacteria were obtained from the National Institute for Environmental Studies (NIES), Japan. The cells of these Microcystis strains were spherical and had diameters ranging from 3.7 to $5.7 \mu \mathrm{m}$ and volumes ranging from 27 to $97 \mu^{3}$ (Table 1). All strains were maintained at $25^{\circ} \mathrm{C}$ in $\mathrm{CB}$ media under a light intensity of 40 to $48 \mu \mathrm{E} \mathrm{m} \mathrm{m}^{-2} \mathrm{~s}^{-1}$ with a $12: 12 \mathrm{~h}$ light:dark cycle. Cultures with organisms in the exponential growth phase were used for feeding experiments.

Two centric diatoms, similar in morphology, were used for the evaluation of food selectivity and quality. The small diatom Stephanodiscus hantzschii UTCC 267 was obtained from the University of Toronto Culture Collection of Algae and Cyanobacteria, Canada (UTCC), while the larger diatom Cyclotella sp. HYK0210-A1 was first isolated by Kang et al. (2005) using the sample from the Gyeongan stream in Korea. The 2 diatom species were cultured and maintained at $15^{\circ} \mathrm{C}$ in DM media under a light intensity of $50 \mu \mathrm{E} \mathrm{m}^{-2} \mathrm{~s}^{-1}$ with a 12:12 h light:dark cycle. Cultures in the exponential growth phase were used for feeding experiments.

Table 1. Mean cell diameter $(\mu \mathrm{m})$, cell volume $\left(\mu \mathrm{m}^{3}\right)$, and microcystin-LR concentration $\left(\mu \mathrm{gg}^{-1}\right.$ dry cells) of toxic and non-toxic strains of Microcystis spp. $(\mathrm{n}>300)$

\begin{tabular}{|lcccc|}
\hline Strain & $\begin{array}{c}\text { Mean cell } \\
\text { diameter }\end{array}$ & $\begin{array}{c}\text { Mean cell } \\
\text { volume }\end{array}$ & $\begin{array}{c}\text { Toxin (LR) } \\
\text { concentration }\end{array}$ & Source \\
\hline M. aeruginosa NIER-10001 & $4.1 \pm 0.39$ & 36 & 1.438 & This study \\
M. aeruginosa NIES-298 & $4.3 \pm 0.49$ & 41 & 0.168 & Yasuno et al. (1998) \\
M. aeruginosa NIES-101 & $3.7 \pm 0.37$ & 27 & 0 & Yasuno et al. (1998) \\
M. viridis NIES-102 & $5.5 \pm 0.93$ & 87 & 0.287 & Yasuno et al. (1998) \\
M. wesenbergii NIES-104 & $5.7 \pm 0.57$ & 97 & 0.004 & Yasuno et al. (1998) \\
\hline
\end{tabular}


Measurement of microcystins. The microcystin concentration of Microcystis aeruginosa NIER-10001 was determined as described by the ELISA method of Nagata et al. (1995a,b). The anti-microcystin M8H5 MAb used in the ELISA recognized almost equally the major microcystin derivatives such as microcystin-LR, microcystin-RR and microcystin-YR. We chose microcystin-LR as the standard for the ELISA as it is the most widely studied microcystin $\left(\mathrm{C}_{49} \mathrm{H}_{74} \mathrm{~N}_{10} \mathrm{O}_{12}=\right.$ 995.17, $250 \mu \mathrm{g}$, Wako). The water specimens to be analyzed were treated twice by freeze-thawing followed by filtration over glass filters (Whatman GF/C, $25 \mathrm{~mm}$ in diameter). The samples or the standards were mixed with an appropriate dilution of M8H5 MAb and added to a 96-well microtiter plate (Coaster) that had been coated with a microcystin-LR bovine serum albumin conjugate. After washing, the bound MAb was detected with horseradish peroxidase-labeled goat anti-mouse IgG (TAGO 4550) and its substrate $(0.1 \mathrm{mg}$ $\mathrm{ml}^{-1}$ of $3,3^{1}, 5^{\prime}, 5^{\prime}$-tetramethylbenzidine and $0.005 \%$ $\mathrm{H}_{2} \mathrm{O}_{2}$ in $0.1 \mathrm{M}$ acetate buffer [pH 5]). The microcystin concentration was determined from the standard competitive curve of microcystin-LR. For the remaining 4 Microcystis strains we used the microcystin contents reported by Yasuno et al. (1998).

Feeding experiments. Based on the concentration of chlorophyll a, Microcystis aeruginosa NIER-10001 $(1 \times$ $10^{6}$ cells ml $\left.{ }^{-1}\right)$, Chlorella ${ }^{\mathrm{TM}}\left(1 \times 10^{6}\right.$ cells ml $\left.^{-1}\right)$, Stephanodiscus hantzschii UTCC $267\left(1 \times 10^{4}\right.$ cells $\left.\mathrm{ml}^{-1}\right)$ and Cyclotella meneghiniana HYK0210-A1 $\left(1 \times 10^{4}\right.$ cells $\mathrm{ml}^{-1}$ ) were used as prey to evaluate food selectivity or quality of the prey fed to the flagellate. All algae were cultured to the exponential growth phase, harvested by centrifugation and separately resuspended in an Erlenmeyer flask containing $300 \mathrm{ml}$ of FSW. We added Diphylleia rotans that had been starved for $2 \mathrm{~d}$ to minimize possible residual growth resulting from ingestion of prey during batch culture, or added no flagellates as a control. The initial prey density was $10^{4}$ to $10^{6}$ cells $\mathrm{ml}^{-1}$, while that of $D$. rotans was $1 \times 10^{3}$ cells ml ${ }^{-1}$. Duplicate cultures were incubated at 20 to $25^{\circ} \mathrm{C}$ under 40 to $48 \mu \mathrm{E} \mathrm{m}^{-2} \mathrm{~s}^{-1}$ with a $12: 12 \mathrm{~h}$ light:dark cycle for $5 \mathrm{~d}$. To monitor the changes in algal and flagellate cell density over time, $5 \mathrm{ml}$ of culture suspension was withdrawn from each flask every $12 \mathrm{~h}$. These samples were fixed with $25 \%$ buffered glutaraldehyde at a final concentration of $1 \%$ and prey density was enumerated using a haemocytometer under a light microscope. Flagellates were counted under an epifluorescence microscope following ultraviolet excitation by the primulin method (Caron 1983).

Because the highest growth of the flagellate was detected with a diet of Microcystis aeruginosa NIER10001 in preliminary experiments, we cultured $M$. aeruginosa NIER-10001 under various temperatures $\left(15,20,25\right.$ and $\left.30^{\circ} \mathrm{C}\right)$ or $\mathrm{pH}$ levels $(5,6,7,8,9$ and 10$)$ to examine the growth requirements of Diphylleia rotans. Changes in flagellate cell density were monitored as described above.

For quantitative examination of the responses of Diphylleia rotans to 5 different Microcystis prey - 4 toxic strains (Microcystis aeruginosa NIER-10001, $M$. aeruginosa NIES-298, $M$. viridis NIES-102, and $M$. wesenbergii NIES-104) and 1 non-toxic strain ( $M$. aeruginosa NIES-101) - we conducted feeding experiments using different densities of the Microcystis strains $\left(0,2,4,6,8,10,30\right.$ and $50 \times 10^{5}$ cells ml ${ }^{-1}$ for each strain) in the presence of $D$. rotans at $1 \times 10^{3}$ cells $\mathrm{ml}^{-1}$. All Microcystis cells were grown to the exponential growth phase, harvested by centrifugation and resuspended at various densities in Erlenmeyer flasks containing $300 \mathrm{ml}$ of FSW. These suspensions were incubated with the flagellate and monitored for flagellate and Microcystis cell densities, as described above.

The specific growth rate $\left(\mu, \mathrm{d}^{-1}\right)$ of Diphylleia rotans was calculated as:

$$
\mu=\left(\ln F_{t}-\ln F_{0}\right) / t
$$

where $F_{0}$ is the initial density of $D$. rotans, and $F_{t}$ is the final density after time $t$.

Ingestion rate ( $I$, prey $\left.\mathrm{HF}^{-1} \mathrm{~d}^{-1}\right)$ was calculated using the equations of Frost (1972) and Heinbokel (1978) as:

$$
I=p \times C \times 24
$$

where $p$ is the mean prey concentration and $C$ is the clearance rate (volume grazer ${ }^{-1} \mathrm{~h}^{-1}$ ). $\mu$ and I of Diphylleia rotans were analyzed using the Michaelis-Menten equations, respectively, as previously described (Jeong et al. 2002).

\section{RESULTS}

Diphylleia rotans showed active growth when feeding on Microcystis aeruginosa (Fig. 1A) and lower (but significant) growth on Chlorella ${ }^{\mathrm{TM}}$ (Fig. 1B). The food vacuole of the flagellate contained 1 to 3 cells of Microcystis or Chlorella ${ }^{\mathrm{TM}}$, and the ingested cells seemed to be decomposed within a few minutes after ingestion.

In contrast, we did not observe any significant flagellate proliferation when fed Cyclotella meneghiniana or Stephanodiscus hantzschii, perhaps due to the difficulty in ingesting the rigid cell, even though the food vacuole of the flagellate contained one cell of $C$. meneghiniana or $S$. hantzschii (Fig. 1C,D).

Growth of Diphylleia rotans was most active when the flagellate was incubated at $25^{\circ} \mathrm{C}$, whereas the flagellate showed a low growth rate at $15^{\circ} \mathrm{C}$ (Fig. 2A). The flagellate grew actively at a pH range of 6 to 9, with less active growth observed at pH 5 to 10 (Fig. 2B). 

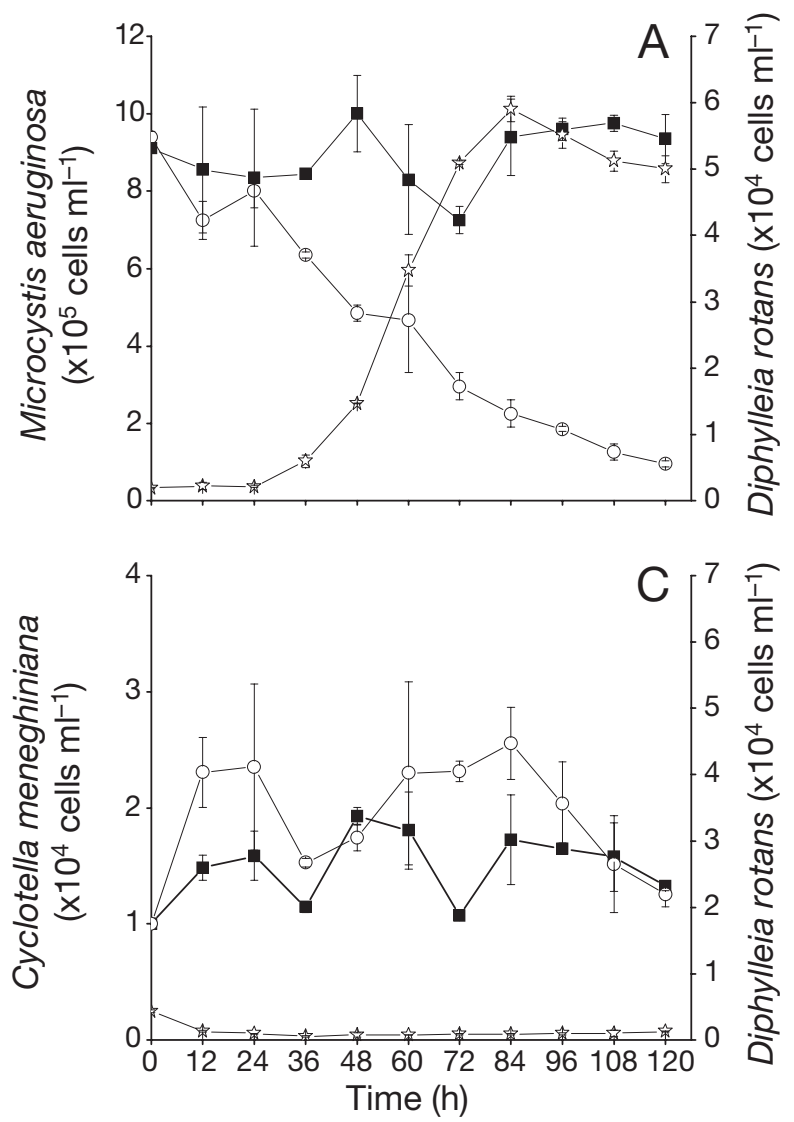


Fig. 1. Diphylleia rotans. Changes in cell density and that of several prey species in the absence (control) and presence (treatment) of $D$. rotans. Vertical bars, which indicate differences in cell abundances between duplicate experiments, are shown when they exceed the size of the symbol

Diphylleia rotans showed different responses to the various Microcystis strains examined in the present study (Figs. $3 \& 4$ ). The maximum numerical specific growth rate $\left(\mu_{\max }\right)$ of $D$. rotans was $1.88 \mathrm{~d}^{-1}$ for $M$. aeruginosa NIER-10001, 1.43 for NIES-298, 1.18 for NIES-101, 1.06 for $M$. viridis NIES-102 and 1.01 for $M$. wesenbergii NIES-104 (Table 2). In terms of the functional responses, the maximum ingestion rate of each Microcystis strain by D. rotans was 27.0 prey $\mathrm{HF}^{-1} \mathrm{~d}^{-1}$ for $M$. aeruginosa NIER-10001, 30.8 for NIES-298, 4.5 for NIES-101 and 15.1 for $M$. viridis NIES-102 (Table 2). The functional response on $M$. wesenbergii NIES-104 did not follow the Michaelis-Menten equation.

\section{DISCUSSION}

Mischke (1994) showed that Diphylleia rotans could graze on Chlorella cf. neustonica, Chlamydomonas sp., Monoraphidium griffithii and Stephanodiscus sp. Here, we showed that $D$. rotans was not only capable of grazing on both Microcystis aeruginosa and Chlo- rella ${ }^{\mathrm{TM}}$ (Fig. 1), but the growth of D. rotans was higher using $M$. aeruginosa as prey than when Chlorella ${ }^{\mathrm{TM}}$ was used. However, using $M$. aeruginosa as a food is inferior to many common species of green algae, such as Chlorella spp. or Scenedesmus spp., probably due to its toxic nature (Gulati \& Demott 1997, Alva-Martínez et al. 2004). However, our findings suggest that despite the toxic nature of $M$. aeruginosa, this algal food may be of better quality and more favorable than Chlorel$1 a^{\mathrm{TM}}$ for $D$. rotans. To our knowledge this is the first report showing that $D$. rotans is capable of grazing on the toxin-producing $M$. aeruginosa.

Under natural conditions Microcystis aeruginosa is a dominant species at temperatures between 20 and $30^{\circ} \mathrm{C}$ and at a $\mathrm{pH}$ range of 8 to 10 . Our results revealed that Diphylleia rotans grows actively at $25^{\circ} \mathrm{C}$ and at a pH range of 6 to 9 (Fig. 2). Thus, although the flagellate prefers slightly more acidic conditions than the alga, the ranges overlap. As the flagellate did not show active growth at $\mathrm{pH} 10$, which is when $M$. aeruginosa is flourishing, our results suggest that the flagellate may put substantial grazing pressure on $M$. aeruginosa at the beginning of its bloom. 


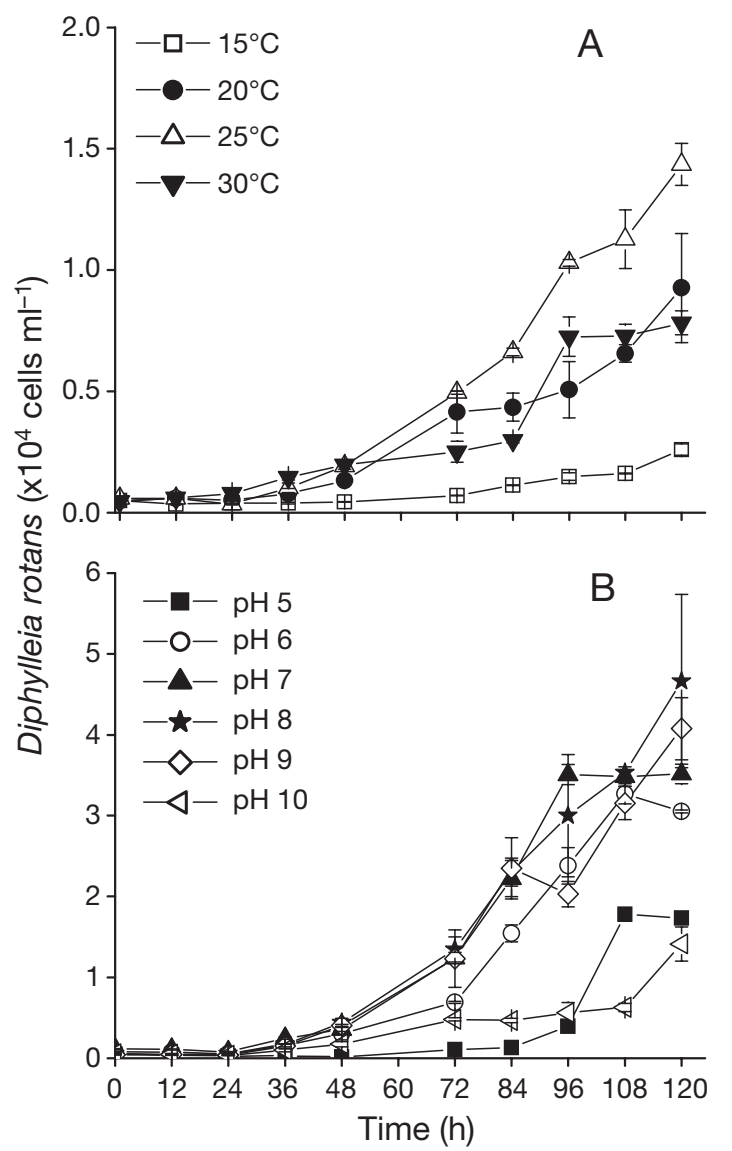

Fig. 2. Diphylleia rotans. Changes in cell density under different (A) temperature and (B) $\mathrm{pH}$ conditions. Vertical bars, which indicate differences in cell abundances between duplicates, are shown when they exceed the size of the symbol

Diphylleia rotans grew more actively on Microcystis aeruginosa than on Chlorella ${ }^{\mathrm{TM}}$, Cyclotella meneghiniana or Stephanodiscus hantzschii (Fig. 1), and the maximum growth rate of $D$. rotans (Fig. 3) was detected when the flagellate fed on $M$. aeruginosa NIER-10001, which is the most toxic of the tested strains (Table 1). Similarly, the maximum ingestion rate of $M$. aeruginosa NIER-10001 by $D$. rotans was high relative to that of other Microcystis strains (Fig. 4). This suggests that $D$. rotans may have a high tolerance to microcystin, or may show microcystin-mediated growth, or both. Although toxic cyanobacteria are usually harmful to zooplankters (Yasuno et al. 1998), some previous studies have reported active flagellate growth on toxic Microcystis spp. Ou et al. (2005) noted that the mixotrophic flagellate Poterioochromonas sp. grew well in the presence of increasing concentrations of microcystin or abundant $M$. aeruginosa, or both, and had the ability to degrade microcystin. Thus, our novel findings suggest that future studies are warranted to measure the changes of microcystin concentrations in algal cells and culture media during grazing experiments as a means to better understand the relationships among microcystin concentrations, flagellate growth and possible microcystin use by heterotrophic nanoflagellates.

While we could calculate the maximum growth rate of the flagellate on Microcystis wesenbergii NIES-104 (Table 2), we were unable to calculate the ingestion rate because we could not detect a clear decrease in M. wesenbergii NIES-104 cell density in the feeding experiment. In general, $M$. wesenbergii NIES-104 provided a lower concentration of microcystin-LR than that of other strains such as $M$. aeruginosa NIES-298 and $M$. viridis NIES-102 (Yasuno et al. 1998), although they are bigger in cell volume. Why a large-sized and less-toxic strain (LSLT) did not induce a higher growth rate of the flagellate compared with a small-sized and more-toxic strain (SSMT) remains unknown. Therefore, although we cannot fully explain why, among 5 Microcystis strains, M. wesenbergii NIES-104 showed relatively high growth even in the presence of Diphylleia rotans and we failed to detect a predation-based decrease in the cell density, this result indicates that toxic $M$. wesenbergii NIES-104 may not be relevant as a food for grazing flagellates. Further study is required to generalize the food selectivity of flagellates like D. rotans, and to understand the survival strategy of LSLT and SSMT phytoplankton in freshwater systems.

In natural lakes Microcystis populations usually form colonies that cannot be eaten by most zooplankters, due to toxin production by the cyanobacteria (Fulton \& Pearl 1987) or the large size of the colonies, or both, which exceed the ranges of size-selective grazing by the zooplankters (Gliwicz \& Siedlar 1980, Thompson et al. 1982). We showed that Diphylleia rotans appears highly tolerant of microcystin, suggesting that the flagellate is capable of over- 

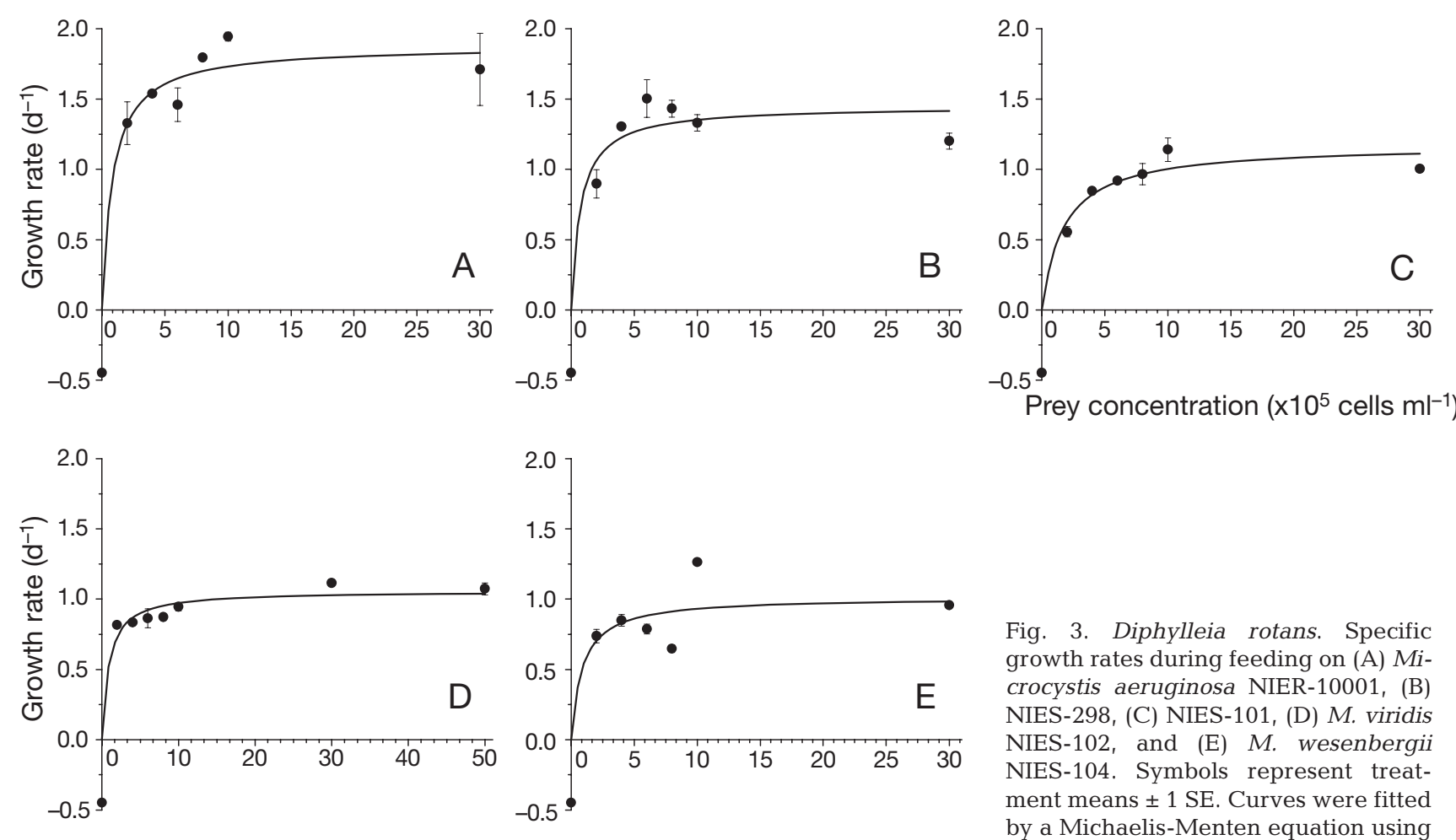

Prey concentration $\left(x 10^{5}\right.$ cells $\left.\mathrm{ml}^{-1}\right)$

Fig. 3. Diphylleia rotans. Specific growth rates during feeding on (A) Microcystis aeruginosa NIER-10001, (B) NIES-298, (C) NIES-101, (D) $M$. viridis NIES-102, and (E) M. wesenbergii NIES-104. Symbols represent treatment means $\pm 1 \mathrm{SE}$. Curves were fitted by a Michaelis-Menten equation using all treatments
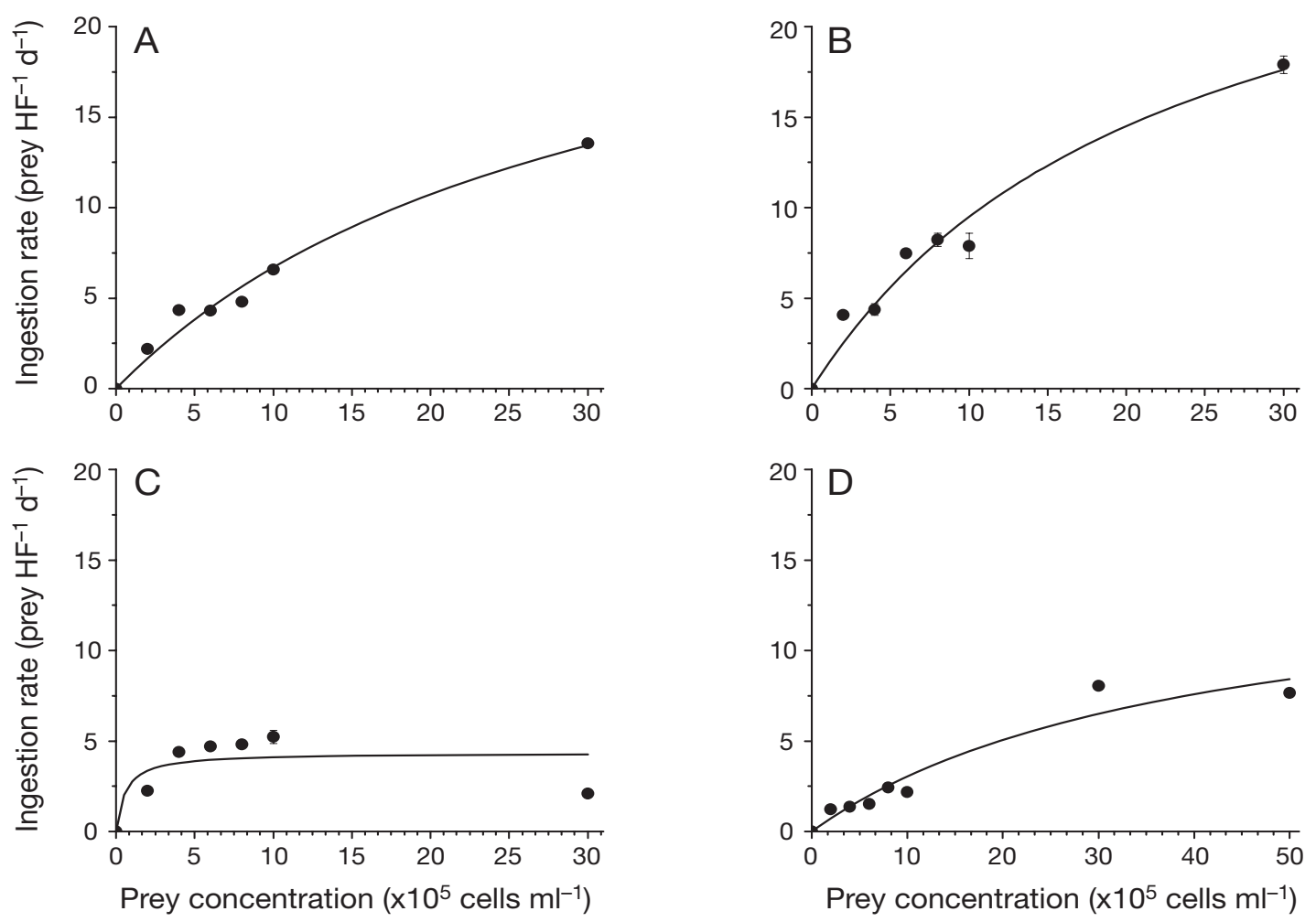

Fig. 4. Diphylleia rotans. Maximum ingestion rates during feeding on (A) Microcystis aeruginosa NIER-10001, (B) NIES-298, (C) NIES-101, and (D) M. viridis NIES-102. Symbols represent treatment means \pm 1 SE. Curves were fitted by a Michaelis-Menten equation using all treatments. HF: heterotrophic flagellate 
coming the limitation that could be produced by the toxin. With regard to size-selective grazing by the flagellate, Mischke (1994) noted that $D$. rotans could feed on algal cells like Monoraphidium griffithii, which is larger than the flagellate, suggesting that the genus Diphylleia may have the ability to ingest large particles. However, we found that $D$. rotans could not grow on Cyclotella meneghiniana $\left(733 \mathrm{\mu m}^{3}\right)$ or Stephanodiscus hantzschii $\left(98 \mu^{3}\right)$, because their cell walls were made of siliceous matter. Although this seems to suggest that the flagellate could not prey on the larger algae due to size-selective feeding or food quality, or both, we noted that the flagellate grew more actively on $M$. aeruginosa compared with Chlorella $^{\mathrm{TM}}$, which has a smaller individual cell size $\left(6 \mathrm{~m}^{3}\right)$ than $M$. aeruginosa. Although further studies are required to examine size-selective grazing by $D$. rotans, we hypothesize that the higher growth of the flagellate on the more toxic $M$. aeruginosa strain compared with that on other prey tested was due to toxin-mediated growth.

Acknowledgements. We thank Dr. J. S. Ki for helpful suggestions regarding the molecular strain identification, and NIES and NIER for providing Microcystis strains. This research was supported by the National Research Laboratory Program (2000-N-NL-01-C-290) of the Korean Ministry of Science and Technology.

\section{LITERATURE CITED}

Alva-Martínez AF, Sarma SSS, Nandini S (2004) Population growth of Daphnia pulex (Cladocera) on a mixed diet (Microcystis aeruginosa with Chlorella or Scenedesmus). Crustaceana 77(8):973-988

Beveridge MCM, Baird DJ, Rahmatullah SM, Lawton LA, Beattie KA, Codd GA (1993) Grazing rates on toxic and non-toxic strains of cyanobacteria by Hypophthalmichthys molitrix and Oreochromis niloticus. J Fish Biol 43:901-907

Brugerolle G, Patterson DJ (1990) A cytological study of Aulacomonas submarina Skuja 1939, a heterotrophic flagellate with a novel ultrastructural identity. Eur J Protistol 25: 191-199

Caron DA (1983) Technique for enumeration of heterotrophic and phototrophic nanoplankton, using epifluoresence microscopy, and comparison with other proceures. Appl Environ Microbiol 46:491-498

Dryden RC, Wright SJL (1987) Predation of cyanobacteria by protozoa. Can J Microbiol 33:471-482

Frost BW (1972) Effects of size and concentration of food particles on the feeding behavior of the marine planktonic copepod Calanus pacificus. Limnol Oceanogr 17:805-815

Fuhrman JA, Suttle CA (1993) Viruses in marine planktonic systems. Oceanography 6:50-62

Fulton RS, Pearl HW (1987) Toxic and inhibitory effects of the blue-green alga Microcystis aeruginosa on herbivorous zooplankton. J Plankton Res 9:837-855

Gliwicz ZM, Siedlar E (1980) Food size limitation and algae interfering with food collection in Daphnia. Arch Hydrobiol 88:195-202
Gulati RD, Demott WR (1997) The role of food quality for zooplankton. Freshw Biol 38:1-771

Hanazato T, Yasuno M (1984) Growth, reproduction and assimilation of Moina macropoda fed on Microcystis and/or Chlorella. Jpn J Ecol (Otsu) 34:195-202

Heinbokel JF (1978) Studies on the functional role of tintinnids in the Southern California Bight. I. Grazing and growth rates in laboratory cultures. Mar Biol 47: 177-189

Jeong HJ, Yoon JY, Kim JS, Yoo DY, Seong KA (2002) Growth and grazing rates of the prostomatid ciliate Tiarina fusus on red-tide and toxic algae. Aquat Microb Ecol 28: 289-297

Kang YH, Kim JD, Kim BH, Kong DS, Han MS (2005) Isolation and characterization of a bioagent antagonistic to diatom, Stephanodiscus hantzschii. J Appl Microbiol 98:1030-1038

Klaveness D (1995) Collodictyon triciliatum H. J. Carter (1865) - a common but fixation-sensitive algivorous flagellate from the limnopelagial. Nordic J Freshw Res 70: 3-11

Manage PM, Kawabata Z, Nakano S (1999) Seasonal changes in densities of cyanophages infectious to Microcystis aeruginosa in a hypereutrophic pond. Hydrobiologia 411: 211-216

Massart J (1920) Recherches sur les organismes inféneurs. VIII. Sur la motilité des Flagellates. Bull Acad R Belge Cl Sci 6:116-141

Mischke U (1994) Influence of food quality and quantity on ingestion and growth rates of three omnivorous heterotrophic flagellates. Mar Microb Food Webs 8(1-2):125-143

Miura T (1990) The effects of planktivorous fishes on the plankton community in a eutrophic lake. Hydrobiologia 200/201:567-579

Nagata S, Soutome H, Tsutsumi T, Sekijima M and 5 others (1995a) Novel monoclonal antibodies against microcystin and their activity for hepatotoxicity. Nat Toxins 3:78-86

Nagata S, Tsutsumi T, Hasegawa A, Watanabe MF, Ueno Y (1995b) Determination of microcystin in environmental water by highly sensitive immunoassay. Jpn J Toxicol Environ Health 41:10

Nakano S, Hayakawa K, Frenette JJ, Nakajima T, Jiao C, Tsujimura S, Kumagai M (2001a) Cyanobacterial blooms in a shallow lake: a large-scale enclosure assay of the importance of diurnal stratification. Arch Hydrobiol 150: 491-509

Nakano S, Manage PM, Nishibe Y, Kawabata Z (2001b) Trophic linkage among heterotrophic nanoflagellates, ciliates and metazoan zooplankton in a hypereutrophic pond. Aquat Microb Ecol 25:259-270

Nishibe Y, Kawabata Z, Nakano S (2002) Grazing on Microcystis aruginosa by the heterotrophic flagellate Collodictyon triciliatum in a hypertrophic pond. Aquat Microb Ecol 29:173-179

Nishibe Y, Manage PM, Kawabata Z, Nakano S (2004) Trophic coupling of a testate amoeba and Microcystis species in a hypertrophic pond. Limnology 5:71-76

Northcott ME, Beveridge MCM, Ross LG (1991) A laboratory investigation of the filtration and ingestion rates of the tilapia Oreochromis niloticus feeding on two species of blue-green algae. Environ Biol Fishes 31:75-85

Ou D, Song L, Gan N, Chen W (2005) Effects of microcystins on and toxin degradation by Poterioochromonas sp. Environ Toxicol 20:373-380

Paerl HW (1983) Factors regulating nuisance blue-green algal bloom potentials in the lower Neuse River. Report No 188, UNC Water Resour Res Inst, Raleigh, NC 
Suttle CA (1994) The significance of viruses to mortality in aquatic microbial communities. Microb Ecol 28: 237-243

Thompson JM, Ferguson AJD, Reynolds CS (1982) Natural filtration rates of zooplankton in a closed system: the derivation of a community grazing index. J Plankton Res 4:545-560

Tucker S, Pollard P (2005) Identification of cyanophage Ma-LBP and infection of the cyanobacterium Microcystis

Editorial responsibility: Urania Christaki,

Wimereux, France aeruginosa from an Australian subtropical lake by the virus. Appl Environ Microbiol 71(2):629-635

Yasuno M, Sugaya Y, Kaya K, Watanabe MM (1998) Variations in the toxicity of Microcystis species to Moina macrocopa. Phycol Res 46:31-36

Zhang X, Watanabe MM, Inouye I (1996) Light and electron microscopy of grazing by Poterioochromonas malhamensis (Chrysophyceae) on a range of phytoplankton taxa. J Phycol 32:37-46

Submitted: March 4, 2006; Accepted: September 26, 2006 Proofs received from author(s): November 14, 2006 